Acta Regionalia et Environmentalica 1

Nitra, Slovaca Universitas Agriculturae Nitriae, 2016, pp. 12-16

\title{
DIFFERENTIATING RURAL AREAS IN UZBEKISTAN AND SLOVAKIA AND THEIR CLASSIFICATION
}

\author{
Aygul ISMAILOVA \\ Slovak University of Agriculture in Nitra, Slovak Republic
}

\begin{abstract}
The characteristic of the concept "rural areas" is widely different, varying from country to country. Similarly, Uzbek rural areas quite differ from Slovak ones. However, in both countries there is not applied a concrete national typology for the classification of rural areas. Therefore, the main aim of the paper is to identify the differences between the rural areas in Uzbekistan and Slovakia and to classify them using the rural - urban typology based on OECD methodology. In the selected countries the rural areas are mainly identified by the number of population living in the rural local units. According to the results of the classification by using the OECD methodology, in Uzbekistan the significantly rural areas prevail whereas in Slovakia, the intermediate ones dominate. However, there is not a big difference in the share of rural population between predominantly rural areas and intermediate ones in the Slovak Republic. In contrast to Slovakia, the number of rural residents in the intermediate rural areas in Uzbekistan is about three times lower than rural population in predominantly rural areas. There is not a predominantly urban area according to this methodology in Uzbekistan, however in Slovakia, Bratislava is the only region considered as predominantly urban area where only $2.2 \%$ of rural population from the total population reside.
\end{abstract}

Keywords: rural areas, definition of rural areas, typology of rural areas, OECD methodology

There is not a concrete definition of "rural" areas; as the more scientific disciplines of rural are being developed, various characteristics are used. Therefore, there is a great diversity of characteristics concerning the definition, scope and components of the concept of "rural".

For example, sociology defines rural areas as a space out of the urban populated areas, with lower population density and small settlements, engaged in agricultural activities, production and services, with a traditional life style, greater social control and decreasing job offers. In geography the issue of rural areas is understood as a concrete territory, set by total cadastral area of settlements identified as rural. Concerning the economic disciplines, the concept of rural areas has been formed as a result of globalization processes where the depopulation of majority part of state and cities related to economic, social and environmental effects resulted in the diversity in the rural areas (Lepadatu, 2012).

Generally, the concept "rural" is identified in international sources in two main approaches: the spatial (regional) approach and sectoral (territorial) approach (Fáziková, 2010).

\section{Material and methods}

The information concerning this topic was obtained in accordance with the selected periods as from 2012 to 2014.
Sources for the definition and classification of rural areas come from the domestic literature, from the studying materials such as "Rural Development" and other articles and monographs. Similarly, foreign literature materials helped in the typology of rural areas: "Remote Rural Regions" (Dijkstra and Poelman, 2008), "OECD regional typology" (http://www. oecd.org/gov/regional-policy/OECD_regional_typology_ Nov2012.pdf ) and "OECD regions at a Glance" (OECD, 2013) served as a source to classify rural areas in both countries.

Besides the studied literature, main legal regulations concerning the defining of rural areas such as Law on Naming Administrative-territorial Units, the Law № 276-I from August 30, 1996 on the "Degree about the decision of administrative-territorial system issues in Uzbekistan and Act No. 369/1990 Coll. on the Municipal Constitution in wording of later regulations in Slovakia were used. The population indicator was obtained from the Regional Statistical Yearbook 2014 of the Slovak Republic and publication from the State Committee of Statistics of the Republic of Uzbekistan on Statistics for 2012.

For classification of rural areas in the studied countries there is used a new urban-rural regional typology derived from the OECD method. The rural areas were classified at territorial Level 3 that is in Uzbekistan at the level of region (uzb. oblast) and in Slovakia at the level of kraj. According to this typology, the rural areas at territorial Level 3 in these countries were divided into three types as predominantly urban areas, intermediate and predominantly rural ones. Correspondingly, if the rural area at the territorial level 3

Contact address: * *Ing. Aygul Ismailova, Slovak University of Agriculture, Faculty of European Studies and Regional Development, Department of Law, Tr. Andreja Hlinku 2, 94976 Nitra, Slovak republic, e-mail: aygul1988@mail.ru 
with the share of population living in rural local units at the LAU2 level is higher than $50 \%$, then it is classified as a predominantly rural region. The rural area at the territorial level 3 is classified as intermediate rural in case the share of population living in rural local units at the LAU2 varies from $20 \%$ to $50 \%$. The urban region is the region with the share of population in rural local unit lower than $20 \%$. In Uzbekistan, to the local unit at the LAU2 level are referred rural settlements represented by kishlaks and auls. However, data for the population for each kishlak and aul was not available. Therefore, regions (oblast) were classified into three types by the total share of urban and rural population as for the whole oblast in Uzbekistan and Slovakia as for the total kraj.

\section{Results and discussion}

\section{Differentiating rural areas in the Uzbekistan Republic and the Slovak Republic}

There is not set up an exact definition of rural areas including economic, administrative, social, ecologic and rural character in the Slovak Republic (Bednáriková and Maur, 2010) as well as in Uzbekistan. However, there are some sources providing description of the definition of rural areas in both countries. This part of the paper describes both Uzbek and Slovak rural areas, which are evidently not the same. Therefore, some differentiations between rural areas in these countries are discussed below (Table 1).

The definition of Uzbek rural areas is mainly set by the legislation. Particularly, the definition of the rural areas are set in the Law on Naming Administrative-territorial Units and the Law №276-I from August 30, 1996 on the "Degree about the decision of administrative-territorial system issues in the Republic of Uzbekistan" as amended with №LRU-714-II from December 3, 2004 and with № LRU-304 from October10, 2011. According to the article 12 of this law rural area called as the term "rural settlements" refers to the localities with less than two thousand inhabitants which are located in the vicinity of industrial or construction enterprises, railway stations or other important objects. The total number of Uzbek rural settlements records 11,017 (Almanac Uzbekistan, 2013).

In Slovakia, the sources defining the rural areas are the Act 369/1990 and Statistical Office of the Slovak Republic. Therefore, these different sources define rural areas on the base of their certain criteria. Rural areas in the Slovak Republic are basically identified by the territorial unit on the local level (LAU 2) - by municipalities (obec in Slovak language). According to the Slovak legislation criterion (Act 369/1990), the rural municipalities are all the municipalities besides those which are declared as urban ones. There are 2890 municipalities in Slovakia based on the sources from the Statistical Regional Yearbook 2015 for $31^{\text {st }}$ of December 2014 (including 3 military districts), of which 138 are declared as towns. The rest 2752 are considered as rural. However, not all urban municipalities fulfill the urban character requirements. The next criterion was carried out by the Statistical Service aiming at the differentiation between towns and municipalities. According to it, municipality refers to rural if the population constitutes less than 5,000 inhabitants. Based on this criterion, the number of such municipalities is 2,759 in the Slovak territory (Fáziková, 2012).

In Uzbek conditions, the territorial unit based on the local level / unit represent the rural settlements which consist of kishlaks (Uzbek name or in English equal to village) or in Kara-Kalpak, Kazakh or Tatar communities are named aul) and auls. Kishlaks and auls constitute several neighbouring localities, whose populations are mainly engaged in agricultural activities and cattle breeding. They are governed under a given rural assembly using the criterion of convenience for local inhabitants. Government bodies are delegated of the right to establish or abolish villages, kishlaks and auls, and modify their territories or names due to the regard for the opinion of the relevant self-

Table 1 Differentiating rural areas in the Uzbekistan Republic and the Slovak Republic

\begin{tabular}{|l||l|l|}
\hline \multicolumn{1}{|l||}{ Title } & \multicolumn{1}{c|}{ Uzbekistan } & \multicolumn{1}{c|}{ Slovakia } \\
\hline \hline Main sources & $\begin{array}{l}\text { - law on Naming Administrative-territorial Units and } \\
\text { the Law №276-I from August 30, 1996 on the“Degree } \\
\text { about the decision of administrative-territorial } \\
\text { system issues in the Republic of Uzbekistan" as } \\
\text { amended with № LRU-714-II from December 3, 2004 } \\
\text { and with № LRU-304 from October 10, 2011 }\end{array}$ & $\begin{array}{l}\text { - act no 369/1990 Coll. on the Municipal } \\
\text { Constitution in wording of later regulations }\end{array}$ \\
\hline $\begin{array}{l}\text { Territorial unit/area defining } \\
\text { rural }\end{array}$ & - rural settlement represent kishlak and aul & - rural municipality represents obec of the Slovak Republic* \\
\hline $\begin{array}{l}\text { Measuring index of rural } \\
\text { and non - rural areas }\end{array}$ & - number of population living in rural settlement & $\begin{array}{l}\text { - all municipalities not declared as towns } \\
\text { - number of inhabitants residing in obec } \\
\text { - population density per sq km }\end{array}$ \\
\hline $\begin{array}{l}\text { Distinguishing criteria of } \\
\text { defining rural from non- } \\
\text { rural areas }\end{array}$ & $\begin{array}{l}\text { - <2000 inhabitants located in the vicinity of industrial } \\
\text { or construction enterprises, railway stations or other } \\
\text { important objects }\end{array}$ & $\begin{array}{l}\text { - rural municipalities - 2890** } \\
\text { - <5000 inhabitants considered as rural } \\
\text { municipalty }\end{array}$ \\
\hline
\end{tabular}

Sources: Own processing according to following sources - Law on Naming Administrative-territorial Units, the Law №276-I from August 30, 1996 on the "Degree about the decision of administrative-territorial system issues; Act 369/1990 as amended. Buchta, 2012; Fáziková, 2012

*http://www.central2013.eu/fileadmin/user_upload/Downloads/outputlib/EURUFU_O3.2.2_Def_of_rural_areas_in_CEU_121016.pdf **as at Dec. 31, 2014 there were 2890 municipalities in the Slovak Republic (including 3 military districts), of which 138 towns according to the source from Regional Statistical Yearbook of Slovakia 2015 
governments (Law №276-I on Degree about the decision of administrativeterritorial system issues in the Republic of Uzbekistan, 1996). There are also so called "united" rural settlements. They are usually united with neighbourhood communities by similar or common traditions, customs and human, business and legal relationships and formulated as entities with common socio-demographic, cultural and spiritual interests as well as with an administrative-territorial divisions, and defined as "mahalla". The size of population in mahallas differentiates between 150 to 1,500 families. There are 1,471 mahallas in Uzbekistan (Bektemirov and Rahimov, 2003).

In Slovakia, the settlement structure of the rural areas makes up many small municipalities. In some places of Slovak countryside, the close location of these municipalities shows the high level of population density (over 150 inhabitants per $\mathrm{km}^{2}$ ), although they do not fulfill the urban requirements in terms of economic, social, environmental functions. A Slovak rural municipality is a rural settlement with small number of residents mainly engaged in housing, agricultural and recreational activities and with typical rural architecture. In Slovakia, there are recognized two types of settlements - compact and dispersed settlements. For example, kopanice, lazy, štále, and rale are the dispersed types of settlements in Slovakia (Fáziková, 2010).

\section{Classification of rurality on the base of regional typology}

The classification of urban and rural areas varies from country to country. Some countries define it on the base of administrative units or built-up areas; others focus on population size or density, or on land use. Consequently, these classifications are too specific for each country; therefore, their comparison is rather difficult. Consequently, taking into consideration these differences, in the 1990s the OECD developed a classification based on the same criterion for all OECD member states. Besides already existing urban and rural regions, a new type of region, "intermediate", was distinguished.

Thus, OECD established a regional typology according to which regions have been classified as predominantly urban (PU), predominantly rural (PR) and intermediate (IN) (OECD, 2010). The OECD regional typology is based on three criteria. The first criterion identifies rural communities according to the population density. The second criterion classifies regions according to the percentage of population living in rural communities. The third criterion is based on the size of the urban centers. In 2010, the criteria for the identification of rural areas have been extended. In 2010, there was published a new urban-rural regional typology in the Eurostat regional yearbook for the utilization of all Commission services. This typology was derived from the OECD method. Consequently, the Eurostat new urban-rural classification consists of three major criteria. (Dijkstra and Poelman, 2011).

First, as it was mentioned before, the rural area is distinguished by the population density in grid cells per $1 \mathrm{~km}^{2}$ and population size of contiguous areas. Secondly, the classification of NUTS 3 is based on the share of the population living in rural areas. The city presence is adjusted as the third criteria.

The category predominantly rural applied to NUTS 3 regions remained the same as well as the criteria applied for urban centers as in the OECD
Regional Typology. Nevertheless, the two other categories, "intermediate" and "predominantly urban" have been shifted from $15 \%$ to $20 \%$ in this typology.

In other words, a region applied to NUTS 3 is identified as predominantly urban if the share of the population living in rural areas is lower than $20 \%$. If the proportion of population residing in rural areas constitutes between $20 \%$ and $50 \%$, the region is classified as intermediate. According to the Eurostat classification, 59\% of the EU population lives in rural regions that exceed $25 \%$ of rural areas according to the UN estimates (Beer et al., 2014).

\section{Classification of rural areas \\ by the rural - urban typology based on OECD method in Uzbekistan and Slovakia}

There is no national typology for the classification of rural areas in the Slovak Republic (Bednáriková and Maur, 2010) and Uzbekistan.

Therefore, in this part of the article, rural areas are classified in these countries using the new rural - urban typology by Eurostat derived from the OECD methodology (European Commision, 2010)

The typology of rural areas in Uzbekistan is classified at Territorial Level 3, that is, at the region (oblast)

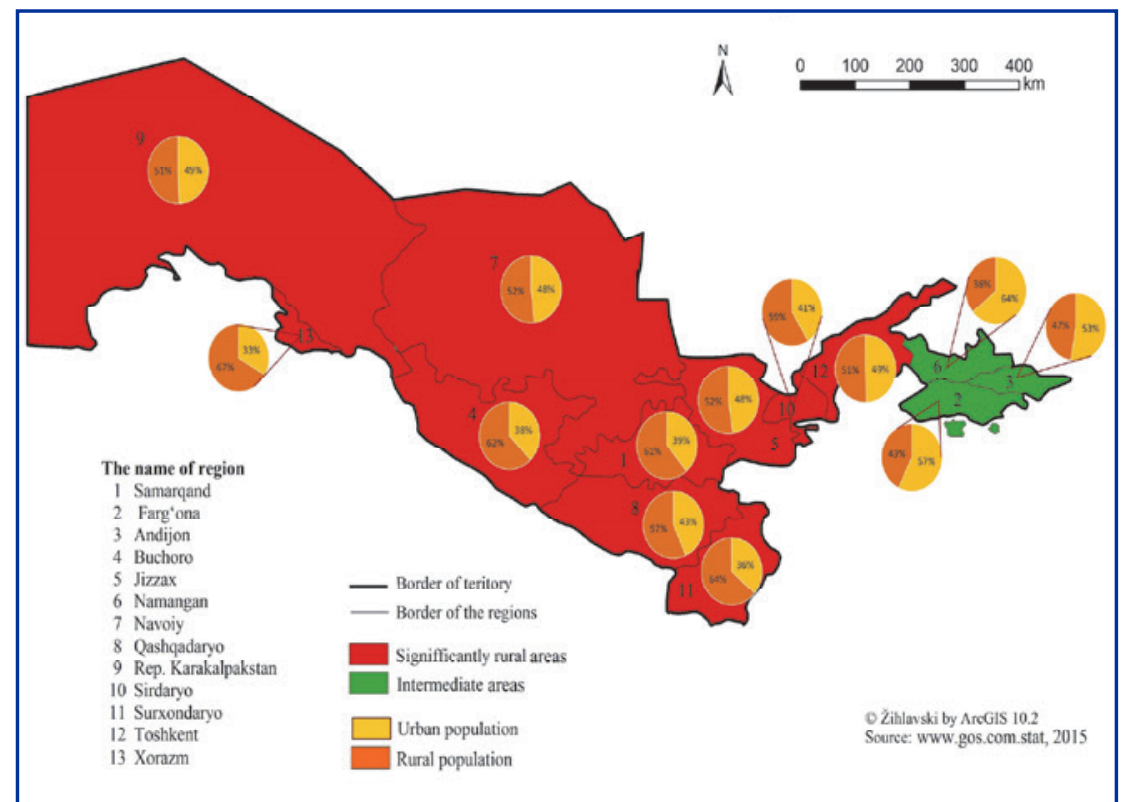

Figure 1 Rurality at the TL3 level (region) in the Uzbekistan Republic as for 2012 Source: Own processing based on the sources from the State Committee of the Republic of Uzbekistan on Statistics, 2012 


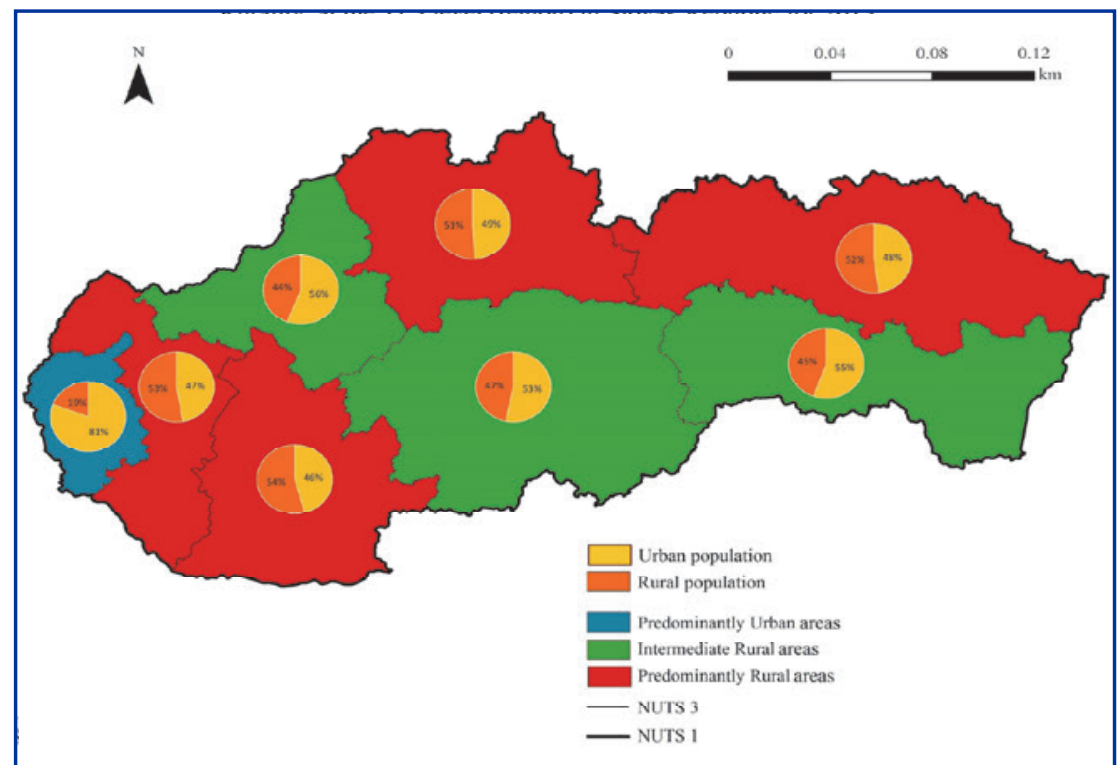

Figure 2 Rurality at the TL3 level (region) in the Slovak Republic as for 2013 Source: Own processing based on the source from Statistical regional Yearbook 2014

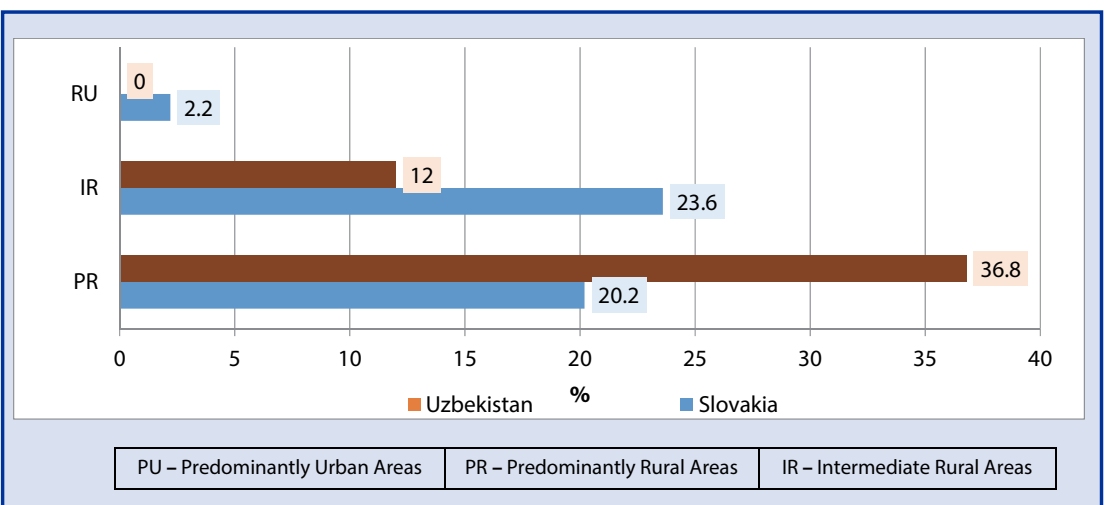

Figure 3

Classification of rural areas by the new urban - rural typology by Eurostat derived from the OECD methodology in Slovakia and Uzbekistan

Source: Own calculations based on OECD methodology according to following sources: Regional Statistical Yearbook prepared by Statistical Office of the Republic of Slovakia, 2014; Bednáriková and Maur, 2010; The State Committee of Statistics of the Republic of Uzbekistan, 2012

level. According to this typology, to classify region into the three types, first, we found the share of rural population at the local units LAU2. In Uzbekistan, to the local units at the LAU2 level are ranked rural settlements represented by kishlaks and auls. However, data for the population for each kishlak and aul was not available. Therefore, regions were classified into three types by the total share of urban and rural population as for the whole region. According to these calculations, there is no urban region in Uzbekistan. There are three regions, Farg'ona, Andijon and Namangan, considered as intermediate rural regions (Figure 1).
The main reasons of the biggest number of urban population in these three regions are:

1. A localization factor as they are located close to the capital city Tashkent and to the Tashkent region which is the leading region in industrial, agrarian and service sectors.

2. Increased concentration of industrial production in these regions (Andijon - 12.4\%, Farg'ona - 7.3\% from the total territorial structure of the industrial production)

3. Location of the main companies as automobile UZDAEWOO, textile companies such as JV "Tagus tekstil"
"Poytugteks", "Samosherteks", "Alërteks" and JSC "Antex" producing gray cloth and cotton yarn and one of the leading enterprises in Central Asia Fergana refinery (FNPZ) dealing with the production of fuels and lubricants (Center for Economic Research, 2014).

The biggest number of urban population among all regions of Uzbekistan represents Namangan with the share of rural population $36 \%$.

In the Slovak Republic, the classification of rural areas at the Territorial Level 3 is identified on the level of regions (in Slovak kraj). Therefore, in the Slovak Republic according to this typology, the Bratislava region is considered as predominantly urban with the share of rural population of about $19 \%$.

Likewise in Uzbekistan, there are three regions (Trenčin, Banska Bystrica and Košice) that are considered as intermediate rural regions in Slovakia (Figure 2).

Based on this methodology, the rest of the regions, Trnava, Nitra, Žilina Banska Bystrica and Prešov in Slovakia and the rest of nine regions and the Karakalpakstan Republic in Uzbekistan are classified as significantly rural regions according to this methodology (Figure 1 and 2).

According to this methodology, the Navoiy region in Uzbekistan is considered as a significantly rural one, however, in Uzbekistan this region could be referred as an intermediate region.

The highest share of rural inhabitants resides in the Xorazm region, equal to $66.8 \%$ (Figure 3 ) in Uzbekistan and respectively the Nitra region with 54\% in Slovakia.

Under the new rural - urban typology by Eurostat derived from the OECD methodology, both countries are classified as rural in terms of rural population.

According to the results, in Uzbekistan there prevail predominantly rural areas with the share of rural population to the total population of $36.8 \%$, whereas in Slovakia, is intermediate rural areas dominate, making up $23.6 \%$ of rural residents. In contrast to Slovakia, the number of rural residents in the intermediate rural areas in Uzbekistan is about three times lower than rural 
population in predominantly rural areas. There is not a predominantly urban area according to this methodology in Uzbekistan, however in Slovakia, Bratislava is the only region considered as predominantly urban area, with only $2.2 \%$ of rural population on the total population.

\section{Conclusion}

In summary, there is not set up an exact definition of rural areas including economic, administrative, social, ecologic and rural character in the Slovak Republic (Bednáriková and Maur, 2010) as well as in Uzbekistan. However, there are sources such as the Law on Naming Administrativeterritorial Units, the Law №276-I from August 30, 1996 on the "Degree about the decision of administrative-territorial system issues in Uzbekistan and Act 369/1990 as amended, the Statistical Service describing the definition of rural areas in these countries. Eventually, according to these above mentioned sources, rural areas in Uzbekistan are named as rural settlements representing kishlaks and auls, in Slovakia - municipality (obec). One of the main differences defining rural areas at the local unit between these countries is the number of population living in the local units. Uzbek rural settlements represent kishlaks and auls, where the population does not exceed two thousand people, whereas in Slovakia, municipality is considered rural by the Statistical service with the population less than five thousand people.

There is not a national typology of rural areas in these two countries. Thus, to classify rural areas in these countries, the new urban-rural regional typology derived by the OECD method has been used.

According to the results of the classification by using the OECD methodology, in Uzbekistan prevail significantly rural areas with $36.8 \%$ share of rural population whereas in Slovakia dominate intermediate (23.6\%) ones. However, there is not a big difference in the share of rural population between predominantly rural areas (20.2\%) and intermediate ones (23.6\%) in the Slovak Republic. In contrast to Slovakia, the number of rural residents in the intermediate rural areas in Uzbekistan is about three times lower than rural population in predominantly rural areas. There is not a predominantly urban area according to this methodology in Uzbekistan, however in Slovakia, Bratislava is the only region considered as predominantly urban area where resides just $2.2 \%$ of rural population as a share of the total population

\section{References}

ALMANAC “Uzbekistan 2013”. 2013. Альманах Узбекистан. Uzbekistan, Tashkent, 2013, 242 pp.

BEDNÁRIKOVÁ-MAUR.2010.Country profile on rural characteristics Slovak Republic. 2010. Assessing the impact of rural development policies (incl. LEADER) In $7^{\text {th }}$ Framework Programme for Research and Technology Development of the European Commission, 23 p. [online]. Retrieved October 2, 2015 from: http://www.rudi-europe. net/uploads/media/Slovakia_WP1_Report_01.pdf

BEER, J. - NICOLE, G. - ERF, R. 2014. New classification of urban and rural NUTS 2 regions in Europe. In Working Paper. No: 2014/3. Netherlands Interdisciplinary Demographic Institute (NIDI), April 2014. $21 \mathrm{p}$.

BEKTEMIROV, K.- RAHIMOV, E. 2001. Local Government in Uzbekistan. In V. M. Popa, I (Ed.), Developing New Rules in the Old Environment, Budapest: LGI/OSIEurope, 2001, pp. 469-520.

BUCHTA, 2012. Vývojové trendy vidieckych a mestských oblastí Slovenska. In Economics of Agriculture, vol. 12, 2012, no. 4, pp. 48-67.

CENTER for Economic Research. 2014. Региональная политика в Узбекистане: фокус на малые города. [online]. Retrieved September 09, 2015 from:http://www.cer.uz/upload/iblock/321/ whlcbghg\%20ldgvshvxeoyc_final.pdf

DIJKSTRA, L. - POELMAN, H. 2008. Remote Rural Regions. In European Union Regional Policy. 2008.8 ps. [online]. Retrieved September 09, 2015 from: http://ec.europa.eu/regional_policy/ sources/docgener/focus/2008_01_rural.pdf

DIJKSTRA - POELMAN. 2011 Regional Typologies. A Compalition. Regional Focus No.01/2011. Directorate-General for Regional Policy, Brussels. [online]. Retrieved October 2, 2015 from: http:// ec.europa.eu/regional_policy/sources/docgener/focus/2011_01_ typologies.pdf

EUROPEAN Commision. 2010. A revised urban-rural typology. In Eurostat regional yearbook 2010. Luxembourg : Publications Office of the European Union, 2010, 264 p. ISBN 978-92-79-145650. [online]. Retrieved September 10, 2015 from: http://ec.europa. eu/eurostat/documents/3217494/5727301/KS-HA-10-001-EN. PDF/1ba3cf6a-5e25-44c1-99f9-fada17625212

FÁZIKOVÁ, M. 2012. Rural Development. Nitra : Slovak University of Agriculture, 2012, p.74-79. ISBN 978-80-552-0949-4.

LAW on Naming Administrative-territorial Units.

LEPADATU, K. 2012. Rural areas - the premise of Romanian agricultural development. In Scientific Papers Series "Management, Economic Engineering in Agriculture and Rural Development", vol. 12,2012 , no. 3, p. 192. ISSN 2284-7995.

OECD 2013. 2013. OECD Regions at a Glance 2013: OECD Publishing. http://dx.doi.org/10.1787/reg_glance-2013-en.

OFFICE for National Economic Planning. 2012. Final definition and delineation of rural areas in central Europe. 2012. In Identifying Rural Potentials work package. 2012. 63ps. [online]. Retrieved September 2, 2015 from: http://www.central2013.eu/fileadmin/ user_upload/Downloads/outputlib/EURUFU_03.2.2_Def_of_ rural_areas_in_CEU_121016.pdf

REGIONAL Statistical Yearbook of Slovakia 2014. In Statistical Office of the Slovak Republic, March 2015. Bratislava. 503 p. ISBN 978-80-8182-374-8.

STATE Committee of the Republic of Uzbekistan on Statistics. 2012. Население Узбекистана в разрезе регионов (цифры). In Газета. uz. [online]. Retrieved September 2, 2015 from: http://www.gazeta. uz/2012/11/14/population

\section{LEGISLATION}

UZBEKISTAN Republic. Law on Naming Administrative-territorial Units

UZBEKISTAN Republic. Law №276-I from August 30, 1996 on the "Degree about the decision of administrative-territorial system issues " as amended

SLOVAK Republic. Act 369/1990 Coll. as amended 